Jurnal Interpretasi Hukum |ISSN: 2746-5047

Vol. 2, No. 2 - Agustus 2021, Hal.378-383 | Tersedia online di https://www.ejournal.warmadewa.ac.id/index.php/juinhum DOI : https://doi.org/10.22225/juinhum.2.2.3444.378-383

\title{
SANKSI HUKUM BAGI PETUGAS LEMBAGA PEMASYARAKATAN YANG TERLIBAT PEREDARAN NARKOTIKA DI LINGKUNGAN LEMBAGA PEMASYARAKATAN
}

\author{
I Kadek Pasek Saputra, I Nyoman Gede Sugiartha \& I Made Minggu Widyantara \\ Fakultas Hukum Universitas Warmadewa, Denpasar-Bali, Indonesia \\ saputrapasek4@gmail.com,nyomansugiartha14@gmail.com, mademinggu21@gmail.com
}

\begin{abstract}
Abstrak
Sebagai negara yang berkembang dengan ideologi negara Pancasila, belum cukup bagi Negara Indonesia untuk mampu mendedikasikan diri sebagai negara yang sejahtera. Dilihat dari perspektif hukum, ada tingkah laku yang sesuai dengan norma yang berlaku dan ada pula tingkah laku yang menyimpang dari norma yang berlaku. Kendati demikian maka perlu adanya sanksi hukum yang mengatur kehidupan berbangsa dan bernegara. Dalam sistem peradilan pidana di Indonesia lembaga pemasyarakatan memiliki kedudukan sebagai tempat pembinaan dan pelaksanaan atas apa yang sudah diputus oleh pengadilan bagi terpidana. Tujuan penelitian ini adalah untuk menelaah penyalahgunaan wewenang yang dilakukan oleh petugas terhadap peredaran narkotika yang terjadi di lembaga pemasyarakatan dan pemberian sanksi hukum bagi petugas lembaga pemasyarakatan yang terlibat pengedaran narkotika di lingkungan lembaga pemasyarakatan. Dalam meneliti peneltian ini, menggunakan metode penelitian normatif, dengan menggunakan pendekatan perundang-undangan, pendekatan konseptual dan pendekatan kasus. Hasil penelitian ini menjelaskan bahwa Penyalahgunaan wewenang petugas lembaga pemasyarakatan diatur dalam UU No. 12 Tahun 1995 Tentang Pemasyarakatan.
\end{abstract}

Kata Kunci: Lembaga Pemasyarakatan, Narkotika, Sanksi Hukum

\begin{abstract}
As a developing country with the state ideology Pancasila, it is not enough for the State of Indonesia to be able to dedicate itself as a prosperous country. Viewed from a legal perspective, there are behaviors that are in accordance with the prevailing norms and there are also behaviors that deviate from the prevailing norms. Nevertheless, it is necessary to have legal sanctions regulating the life of the nation and state. In the criminal justice system in Indonesia, the correctional institution has a position as a place of guidance and implementation of what has been decided by the court for the convicted person. There are two problem formulations that will be discussed further related to the criminal act of looting, including how the classification of abuse of power carried out by prison officers against the circulation of narcotics that occurs in prisons and how to impose legal sanctions for prison officers who are involved in narcotics trafficking in prisons? From the formulation of the problem, the discussion is carried out using normative research methods. The abuse of authority of correctional officers is regulated in Law no. 12 of 1995 concerning Correctional Facilities.
\end{abstract}

Keyword: Legal Sanctions, Correctional Indtitutions, Narcotics

\section{PENDAHULUAN}

Kejahatan merupakan suatu tindakan disertai perilaku yang pastinya sangat merugikan dan meresahkan masyarakat sekitar. Hal ini tentunya sama sekali tidak diharapkan oleh masyarakat, dikarenakan begitu sangat tidak diuntungkan. Maka dari itu pemerintah yang merupakan salah satu pemegang keputusan harus bisa mengatasinya dengan keputusan yang tegas dan bijak agar terciptanya suatu ketentraman serta kedamaian ditengah masyarakat.

Perlu diketahui Indonesia merupakan suatu negara berkembang yang sangat memegang teguh ideologi negara yaitu Pancasila, walaupun sudah memiliki ideologi yang sangat baik, akan tetapi tetap perlu adanya suatu hukum yang bisa mengatur jalannya kehidupan berbangsa dan bernegara (Arief, 2001). Sebagaimana diatur dalam Pasal 1 ayat (3) UUD NRI 1945 
bahwasannya negara Indonesia merupakan negara hukum, dengan adanya kepastian seperti itu maka dapat dimaknai bahwa segala kegiatan ataupun aktivitas pada negara Indonesia diatur dengan cara normatif. Serta dengan adanya suatu keberadaan hukum yang berlaku di Indonesia tersebut tentunya sangat memberikan dampak yang begitu sangat baik serta menciptakan suatu ketertiban, dikarenakan dapat menekan kegiatan dan segala aktivitas kejahatan berbagai macam ragam yang terjadi ditengah masyarakat.

Tindakan kejahatan dapat ditekan keberadaanya dikarenakan adanya sanksi yang diberikan seperti pelaku yang melakukan tindakan kejahatan yang sudah divonis penjara maka akan mendapatkan masa hukuman penjara di lembaga pemasyarakatan. Lembaga yang dimaksudkan ini adalah sebuah institusi teknik pada jajaran kementrian hukum dan hak asasi manusia dan perlu dipahami bahwa lembaga ini merupakan wadah atau tempat bagi orang yang sudah di vonis hukuman akibat perbuatan melanggar hukum yang dilakukannya.

Dahulu lembaga pemasyarakatan dikenal dengan sebutan rumah pengajar, yaitu tempat saat orang yang memiliki vonis yang sudah diberikan oleh hakim yang tentunya memiliki kewajiban menjalankan hukum yang diberikan kepada orang yang melanggar hukum. Pemberian sebutan seperti rumah pengajar tersebut dikarenakan agar pemasyarakatan tidak dikenal sebagai tempat hanya memidana seseorang saja tetapi untuk tempat yang bisa memberikan binaan serta mendidik seseorang terpidana tersebut. Guna memberi binaan tersebut dikarenakan agar orang tersebut mendapatkan keahlian seperti mudah bergaul serta bersosialisasi dan menyesesuaikan keadaan diri saat sudah keluar dari dalam lapas.

Lembaga pemasyarakatan memiliki fungsi yang tentunya sangat baik bagi perubahan yang dialami oleh orang yang melakukan pelanggaran hukum tersebut menjadi lebih baik daripada sebelumnya dan tidak mengulangi kesalahan yang sudah dilakukannya dikarenakan efek jera yang diberikan dalam masa kurungan tersebut (Priyatno, 2005). Akan tetapi fungsi dari lapas ini sedikit ternodai akibat beberapa oknum dari dalam yaitu petugas lembaga pemasyarakatan itu sendiri menjadi pelaku tindak pidana seperti melakukan peredaran narkotika didalam lapas tersebut, yang tentunya sangat mencoreng peradilan pidana di Indonesia. Sebagaimana fungsi dari lapas tersebut tentunya harus memberikan dampak yang baik akan tetapi faktanya justru terkadang hal seperti tersebut malah datang dari beberapa oknum penjaga lapas yang berbuat tidak terpuji.

Ada beberapa peneltian yang relevan dengan penelitian ini. Penegakkan hukum peredaran narkotika di lapas dan rutan (Suhayati, 2015). Salah satu bentuk penegakkan hukum adalah pemberian sanksi, penerapan sanksi terhadap narapidana yang melakukan peredaran narkotika dari dalam Lembaga masyarakat (Syahputra, 2017). Kemudian pada penelitian terakhir menjelaskan bagaiamana pemberatan pidana bagi petugas Lembaga pemasyarakatan yang terlibat dalam peredaran narkotika (Saskara, 2019). Berdasarkan penjelasan sebelumnya kemudian peneliti memutuskan untuk mengkaji sanksi hukum bagi petugas yang terlibat peredaran narkoba. Tujuan penelitian ini adalah untuk menelaah penyalahgunaan wewenang yang dilakukan oleh petugas terhadap peredaran narkotika yang terjadi di lembaga pemasyarakatan dan pemberian sanksi hukum bagi petugas lembaga pemasyarakatan yang terlibat pengedaran narkotika di lingkungan lembaga pemasyarakatan

\section{METODE PENELITIAN}

Tipe penelitian yang digunakan dalam Penelitian ini adalah menggunakan tipe hukum normatif yaitu menganalisis kepustakaan berdasarkan bahan hukum yang digunakan, baik primer maupun sekunder (Efendi \& Ibrahim, 2016). Sedangkan jenis pendekatan yang digunakan dalam penelitian ini adalah pendekatan perundang- undangan, pendekatan konseptual dan pendekatan kasus. Dengan menggunakan bahan hukum primer berpedoman tehadap undang-undang dan keputusan yang mengikat dan kemudian dikelompokkan sesuai dengan hierarki perundangundangan (Iswara et al., 2019). Data sekunder adalah data yang diperoleh melalui studi kepustakaan yang berupa bahan tertulis seperti buku teks, peraturan perundang- undangan dan data dari instansi atau lembaga tempat penelitian yang berhubungan dengan masalah yang 
dibahas dalam penelitian. Didapatkan melalui kamus hukum serta ensiklopedia yang berkaitan mengenai informasi hukum. Hal ini dilakukan dengan teknik inventarisasi atau penelusuran bahan hukum yang bersangkutan lalu di klasifikasi atau dikelompokan dan didokumentasikan, dicatat, dikutip, diringkas, diulas sesuai kebutuhan dengan pendekatan kualitatif yang menghasilkan data deskriptif analitis. Menganalisis penelitian ini menggunakan teknik bersifat sistematis dengan disajikan secara deskriptif-analitis, yaitu dengan mendeskripsikan bahan hukum terlebih dahulu secara sistematis kemudian menganalisa melalui teknik analisis dengan teknik tafsiran dan menggunakan argumentasi yang bertumpu pada logika hukum dengan deduktif-induktif.

\section{HASIL DAN PEMBAHASAN}

\section{Klasifikasi Penyalahgunaan Wewenang Yang Dilakukan Oleh Petugas Lembaga Pemasyarakatan Terhadap Peredaran Narkotika Yang Terjadi Di Lembaga Pemasyarakatan}

Lembaga Pemasyarakatan atau lebih sering kita kenal dengan nama sebutan lapas merupakan sebuah binaan untuk seorang narapidana. Tentunya hal ini berfungsi untuk menjadikan seorang narapidana menjadi lebih baik lagi ketika sudah selesai masa kurungannya atau sudah keluar dari lapas tersebut. Tujuan dari lapas sendirinya adalah untuk menjadikan seorang lebih baik lagi dan tidak mengulangi tindak pidana yang sudah dilakukannya.

Tentunya hal ini juga dapat dijelaskan pada keputusan Menteri Republik Indonesia No 6 Tahun 2013 menjelaskan bahwa lapas ialah yang memberikan binaan, menampung serta merawat seorang narapidana tersebut. Dalam hal ini narapidana bukanlah hanya sebuah objek tetapi dapat dikatakan sebagai subjek yang tentunya sama pada manusia pada umumnya seperti mempunyai kelalain ataupun kesalahan. Penyebab atau faktornya yang harusnya kita berantas, maka dengan adanya sanksi kurungan didalam lapas tersebut merupakan solusi terbaik untuk melakukan perubahan pada diri narapidana, hal tersebut tentunya dilakukan untuk menyadari serta menyesali perbuatan mereka yang lakukan itu salah dan pastinya agar mereka menjadi lebih baik lagi. Tetapi tidak hanya saja faktor penyesalan saja yang dapat merubah narapidana menjadi lebih baik lagi, akan tetapi didukung oleh petugas lembaga pemasyarakatan (Effendi, 2011). Sebagaimana diketahui bahwa tugas serta tanggung jawab yang begitu berat diberikan kepada petugas lapas, dikarenakan petugas lapaslah tiap harinya berinteraksi dengan narapidana maka secara tidak langsung petugas lapas sangat berperan dalam merubah sikap serta perilaku dalam lapas.

Penjaga tahanan atau bisa disebut (Sipir) merupakan seorang yang tiap harinya terlibat pada kegiatan dilapas ataupun rutan, maka apapun yang dilakukan didalam lapas atau segala aktivitas maka penjaga tahanan tentunya terlibat, dikarenakan petugas lapas harus ada tiap harinya di dalam lapas, untuk mengurus seluruh narapidana yang ada didalam lapa tersebut (Adji, 2002). Serta apabila terjadi sebuah pelanggaran didalam lapas tersebut tentunya penjaga tahananlah yang harus turun tangan untuk mengatasinya, sudah menjadi kewajiban dari seorang sipir untuk menjaga lapas agar tetap aman dan tidak ada pelanggaran hukum apapun didalam lapas. Yang tentunya tetap mengedepankan aspek bahwa petugas lapas harus menjaga dan membina narapidana didalam lapas.

Lembaga yang membawahi langsung lapas adalah kantor wilayah Kemenkumham, maka hal apapun yang terjadi secara langsung dilapas harus diketahi langsung kepada kanwil. Dan apabila terjadi sebuah pelanggaran hukum dan tidak diberikan sebuah penyelesaian masalah dari penjaga tahanan dan bahkan penjaga tahanan terlibat dalam kegiatan yang melanggar hukum tersebut maka yang memiliki kewajiban untuk menegakan pelanggaran ini adalah kanwil Kemenkumham sebelum masalah ini dibawa pada pihak berwenang atapun kepolisian.

Maka dari itu Ketika terjadi sebuah permasalahan atau suatu kegiatan yang melanggar hukum yang melibatkan penjaga tahanan kanwil Kemenkumham tentunya harus memberikan sanksi secara tegas ataupun menindak lanjuti masalah yang terjadi sebagaimana dilakukan sesuai pada 
wewenang. Tentunya proses yang dilakukan diharapkan harus dilakukan dengan cepat, agar tidak terjadi terhambatnya pembinaan di dalam lapas tersebut.

Dalam hal ini sebenarnya pegawai pemasyrakatan sudah memiliki pegangan peraturan dalam menjalankan tugasnya seperti yang diatur pada PERMENKUMHAM RI No. M.HH-16 KP.05.02 Tahun 2011 mengenai tentang Kode Etik Pegawai Pemasyarakatan Pasal 1 angka 1 yang dimana menjelaskan bawah yang merupakan kode etik ialah pedoman mengenai sikap maupun perbuatan sipir yaitu menjalankan fungsi seperti pembinaan serta membibing para narapidana atau warga binaan pemasyarakatan tersebut dan disertai dengan mengelola benda yang menjadi sitaan atapun barang hasil rampasan (Ali, 2015).

Maka ketika terjadi sebuah pelanggaran hukum terjadi didalam lapas sebaiknya dapat diselesaikan langsung oleh penjaga lapas yang menjaga narapida terpidana tersebut, akan tetapi ketika terjadi pelanggaran yang melibatkan penjaga tahanan itu sendiri maka akan menimbulkan citra yang sangat buruk terhadap lembaga hukum tentunya di Indonesia sendiri, serta pandangan masyrakat terhadap lapas yang seharusnya dapat menjadi wadah untuk seorang narapidana merubah dirinya malah sebaliknya, yaitu menjadikan narapidana menajadi semakin buruk setelah keluar dari lapas. Atas dasar itu sebaiknya penjaga lapas memang benar-benar dapat memegang teguh apa yang menjadi kode etik dalam bekerja melaksanakan pekerjaannya menjadi penjaga lapa. Bukannya hanya sekedar pekerjaan untuk dirinya sendiri saja, akan tetapi penjaga lapas harus sungguh-sungguh menjalankan kewajibannya dengan sebaiknya.

\section{Pemberian Sanksi Bagi Petugas Lembaga Pemasyarakatan Yang Terlibat Pengedaran Narkotika Di Lingkungan Lembaga Pemasyarakatan}

Kata sanksi merupakan sebuah kata yang sering dipakai pada hal aturan mengenai hukum di lingkungan masyarakat, selain itu salah satunya yakni pada KUHP penggunaan kata sanksi pada KUHP sering dikatakan sebagai pidana saja (punishment). Istilah tindak pidana adalah sebuah hal masalah yang dimana sangat berhubungan erat pada masalah kriminalisasi. Tentunya tindak pidana memiliki unsur-unsur serta pengertiannya lebih banyak lagi, pada dasarrnya tindak pidana harus memiliki unsur yang objektif dan subjektif.

Seperti beberapa dari tinjauan kasus tindak pidana yang terjadi pada Lembaga pemasasyarakatan, salah satunya yang terjadi adalah mengedarkan narkotika di dalam lapas yang dilakukan oleh petugas lapas itu sendiri. Sebagaimana dijelaskan dalam pasal 114 UUD RI No. 35 Tahun 2009 mengenai Narkotika menjelaskan dengan sangat jelas bahwa setiap siapapun itu yang melawan hukum seperti menawarkan dan menjadi penyambung jual beli dapat dikenai sanksi berupa penjara paling sebentar lima tahun tentunya terdapat hukuman paling lama yaitu selama dua puluh tahun dan juga hukuman mati dapat diterima oleh sipir yang mengedarkan narkotika ini.

Pada hakikatnya kode etik pada petugas lapas seharusnya dijalankan dengan baik oleh petugas yang menjalankan pekerjaanya tersebut. Dengan adanya kode etik tersebut sudah dipastikan bahwa setiap petugas lapas yang melanggar kode etik dapat diberikan hukuman berupa sanksi yang berlaku. Apalagi pelanggaran yang dilakukan berat seperti mengedarkan narkotika didalam lapas, sebagaimana hal tersebut sudah diatur di dalam perundang-undangan di Indonesia.

Petugas lapas atau sipir yang melanggar akan memperoleh sanksi berupa pidana dan sanksi administratif yang didapatnya. Perlu dipahami bahwa sanksi administrasi diberikan pada perbuatan pelaggarannya, akan tetapi sanksi pidana yaitu diberikan untuk si pelanggar. Selain itu sanksi dari dua tersebut memiliki penegakan hukum yang berbeda. Hal mengenai sanksi kode etik tersebut juga diatur di dalam peraturan menteri. Sanksi dapat diberikan apabila ada yang mengadukan atau membuat pengaduan tindakan pelanggara kode etik yang dilakukan oleh petugas lapas, tahap proses setelah adanya aduan tersebut akan menjalani pemeriksaan 14 hari. Setelah itu majelis kode etik akan memberikan keputusan. Keputusan dapat dikeluarkan setelah memeriksa sipir yang melanggar kode etik. 
Tentunya dalam melakukan pelanggaran kode etik tersebut petugas lapas memiliki beberapa dorongan atau faktor mengapa sampai bisa melakukan hal itu, faktor ekonomi merupakan hal yang paling sangat umum terjadi, ketika sebuah kejahatan itu lahir. Dorongan ekonomi dengan banyaknya jumlah pengeluaran untuk membiayai kehidupan untuk diri sendiri atau untuk keluarga belum tercukupi sehingga menyebabkan tindakan kejahatan muncul dan adanya dorongan untuk memenuhi ekonomi secara mendesak. Maka dari itu terdoronglah petugas lapas untuk melakukan pelanggaran kode etik dikarenakan dorongan faktor ekonomi yang didapatkannya. Hal inilah yang mendasari atau melatar belakangi terjadinya sebuah tindakan pelanggaran kode etik di dalam lapas sehingga tidak bisa dihindari.

Faktor rendahnya mental yang dimiliki oleh sipir, menjadi dasar paling utama untuk mempertahankan kode etik yang berlaku pada petugas lapa. Dengan adanya mental yang rendah tersebut tentu bisa menjadikan diri seorang sipir menjadi cepat melalaikan tugas mereka. Berikutnya yaitu sisten pengawasan di lapas kurang baik menyebabkan terjadinya sebuah sistem yang kacau, sehingga menimbulkan beberapa pelanggaran. Baik itu dari seorang petugasnya ataupun dari narapidana yang ada dialam lapas tersebut. Kasus seperti ini bisa menjadikan lapas menjadi kurang baik itu narapidana didalamnnya. Banyaknya pecandu narkoba di dalam lapas termasuk salah satu pendorong tindakan peredaran narkotika didalam lapas, diakarenakan masih banyaknya narapidan yang ingin memakai narkotika tersebut didalam lapas. Sehingga menyebabkan terjadi pelanggaran yang terjadi.

\section{SIMPULAN DAN SARAN}

\section{Simpulan}

Dari pemaparan hasil penelitian diatas dapat disimpulkan sebagai berikut:

1. Klasifikasi penyalahgunaan wewenang yang dilakukan oleh petugas lembaga pemasyarakatan terhadap peredaran narkotika yang terjadi di Lembaga Pemasyarakatan pada hakikatnya petugas lapas mempunyai kewajiban yang harus dijalankannya didalam lapas, seperti memberikan binaan yang baik kepada narapidana yang tentunya berlandaskan pada kode etik yang berlaku. Guna menciptakan lapas yang menjalani peraturan yang berlaku. Tentunya dengan adanya beberapa pelanggaran kode etik yang berlaku, menyebabkan terjadinya lapas menjadi tercoreng dikarenakan oleh dari akibat oknum petugas yang melanggar kode etik tersebut maupun pidana yang dilakukannya, Sudah sangt jelas bahwa pelanggaran kode etik tersebut mencemari lembaga hukum yang ada di Indonesia. Pelanggaran kode etik ini dapat diberikan sanksi bagi yang melanggarnya. Baik itu sanksi pidana maupun administrasi.

2. Pemberian sanksi hukum bagi petugas lembaga pemasyarakatan yang terlibat pengedaran narkotika di lingkungan Lembaga Pemasyarakatan dapat diberikan sanksi administratif sebagaimana dapat dikatakan sanksi tersebut adalah berupa penurunan pangkat atau bisa sampai pada pemecatan jabatan dikarenkan hal ini sudah melanggar pidana yang berlaku. Sebagaimana yang diatur pada 114 UUD RI No 35 Tahun 2009 mengenai Narkotika menjelaskan dengan sangat jelas bahwa setiap siapapun itu yang melawan hukum seperti menawarkan dan menjadi penyambung jual beli dapat dikenai sanksi berupa penjara paling singkat 5 (lima) tahun tentunya terdapat hukuman paling lama yaitu selama 20 (tahun) dan juga hukuiman mati dapat diterima oleh sipir yang mengedarkan narkotika ini. Maka sanksi pidana inilah sangat memberikan efek jera kepada oknum petugas yang melakukan pelanggaran kode etik dan sanksi pidan tersebut.

\section{Saran}

Dari hasil penelitian skripsi ini terdapat dua saran yaitu:

1. Bagi pemerintah klasifikasi penyalahgunaan wewenang yang dilakukan oleh petugas Lembaga pemasyarakatan, peran Pemerintah sangat diharapkan untuk melakukan peningkatan mutu Sumber daya manusia Petugas Lembaga Pemasyarakatan baik dari 
pengetahuan tentang narkoba maupun peningkatan kesejahteraan sehingga benar-benar dapat menjaga peredaran narkoba di dalam Lembaga pemasyarakatan.

2. Bagi Aparat Penegak Hukum dalam pemberian sanksi hukum bagi petugas lembaga pemasyarakatan yang terlibat pengedaran narkotika di lingkungan Lembaga Pemasyarakatan sepatutnya benar-benar tegas memberikan sanksi yang dapat membuat oknum petugas yang melanggar kode etik maupun pidana didalam lapas dapat diberikan sanksi yang sepadan atas dasar dari perbuatannya tersebut. Dimana yang seharusnya petugas lapas melakukan pembinaan malah justru kebalikannya, yaitu menjadi pengedar narkotika. Maka sangat diharapkan untuk aparat penegak hukum untuk memperketat lapas dalam segi pengawasan terhadp oknum pertugas di dalam lapas. Sehingga tidak menyalahgunakan wewenang yang sudah diberikan kepada petugas tersebut

\section{DAFTAR PUSTAKA}

Adji, I. S. (2002). Korupsi dan Hukum Pidana. Kantor Pengacara dan Konsultan Hukum, Jakarta.

Ali, M. (2015). Dasar-Dasar Hukum Pidana (Cet.3). Sinar Grafika, Jakarta.

Arief, B. N. (2001). Masalah Penegakan Hukum dan Kebijakan Penanggulangan Kejahatan. Citra Aditya Bakti, Bandung.

Efendi, J., \& Ibrahim, J. (2016). Metode Penelitian Hukum: Normatif dan Empiris. Kencana, Jakarta.

Effendi, E. (2011). Hukum Pidana Indonesia Suatu Pengantar (Cet.1). Refika Aditama, Bandung.

Iswara, I. G. N. B. M., Nahak, S., \& Mahendrawati, N. L. M. (2019). Kepastian Hukum Pengenaan Pajak Penghasilan Transaksi Jual Beli Tanah dan/atau Bangunan. Jurnal Prasada, Vol.6(1).

Priyatno, D. (2005). Sistem Pelaksanaan Pidana Penjara di Indonesia. Refika Aditama, Bandung.

Saskara, H. S. (2019). Pemberatan Pidana Bagi Petugas Lembaga Pemasyarakatan yang Terlibat Peredaran Narkotika di Lingkungan Lembaga Pemasyarakatan Fakultas Hukum, Universitas Airlangga.

Suhayati, M. (2015). Penegakan Hukum Peredaran Narkoba di Lapas dan Rutan. Jurnal Info Singkat Hukum, Vol.7(8).

Syahputra. (2017). Penerapan Sanksi Terhadap Narapidana yang Melakukan Peredaran Narkotika dari Dalam Lembaga Pemasyarakatan Kelas II A Kota Bengkulu. Fakultas Hukum, Universitas Bengkulu. 